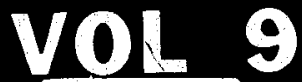

MICROFILMED-1974 


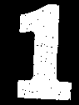

https://doi.org/10.1017/S0084255900005854 


\section{Foreign Policy and the Democratic Process}

Max Beloff. Johns Hoptins. 144 pp. $\$ 1.45$ [papor].

In a series of lectures delivered to on Ameriesn university audi. onea in 1954. Profesuer Belof, en Oxford historien, diecussed the problemt and practico-ospecially in the U.S - of democratic foroign-poliey making. These loetures are now available in a paparback odition with a new spilaguse contributed by the author.

\section{Perspective in Foreign Policy}

Charlos E, Osgood, author \& publither. 62 pp. 50 cents [papar]. Dr. Ongood is a psychologist in the field of communications who has sorved as concultant to the Air Foree, tho Nary, and tho Arms Control and Disarmament Agency. Ho describes hera; as in his oarlier work An Alternotive to War and Sutrender. a strategy of "ealculated de-osedolotion" known by its initials as GRIT, and he relates this strategy to America's Vietnam policy.

\section{Soviot Disarmamont Policy 1917-1963}

Waltec C. Clemans, Ji., compilar. Hoover Institution, 151 pp. 54 - Dr. Clemens; of the Mit faculty, has compiled an asnotated bibliogrophy of arer 200 primery. and secondary sources which are intendad to provide "the widest possible fomiliatity with idoo- logieat: political, military and technical foctors" affecting Soriot disarmament poliey. Although many Russian language publications ara sitod. Communist English longuage publications and Wastarn and U.N. sources are widely reprosented.

\section{The Vletuan Reader}

Mareus G. Raskin B Bernard B. Fall, ods. Random Houte. $4 / 5$ po. $\$ 5.95 \$ 2.45$.

This is a far-reseching, woll-roundod colloction of articlos, speecher and documents on "the war in Viotnam por so and ... its relationship to the continuing erisis in American fareign poliey." Governmant leaders on both sides, "interested" foreign "bystanders" and American abservers are among those whoso viows ace aired hare. Thare ore a usoful shronology and bibliography.

\section{The Decition to Drop the Bemb}

Len Giovannit: \& Fred Freed. Coward-MeCann. 348 pp. \$6.00.

The authors have written a "political histery" of the 113 doys which preceded the Hiroshime bombing when American officials and seientists, and s naw Prosident, "wrestlo[d] with the problem of whather or haw to use the naw wason." Concurrent develepments in Japan are peconstrueted, too, from a varioty of seurces, including memoirs and extensive personal interviews.

By special arrangement with the Foreigh Policy Association, readers of worldvicw may obtain any book published in the United States (except paperbacks) from the FPA's World Affairs Book Center, at the publisher's list price. Post free for domestic orders only. Send orders with check or moniey order to Desk.WV, World Afairs Book Center. 345 East 46 ith Street, New York, N.Y. 10017.

\section{worldview}

WORLOViEW is published monthly (axcopt for a combined July. Auguss istue) by the Cauncil on. Religion and intornational Affatro Subseription: $\$ 400$ por yoar.

Address: 170 East bath Stroet, Now York. Now York 10021

EDITORIAL BOARD

James Finn, Editor

$$
\text { A. William Loos }
$$$$
\text { William J. Cook }
$$

John R. Inman Charies Frankel

Editorial Assistant, Susan Woolfson

\section{CONTEHTS}

A Crisis of Credibility Editorial

In the Magazines 2

Notes on the Dialogue 4 Thomas Molnar

Christianity and Atheism: A Dialogue?

Peter J. Riga

\section{BOOKS}

Protect the United Nations from Its Friends William E. Moran, Jr.

Current Reading

Oplntons exprosied in WORLDVIEw are thate of the avthors, and nat necesserily of the Counclit on Religian and Internatlonal Affeirs.

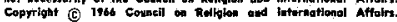

woridview 170 East ofth Stroet New York, N.Y. 1002!

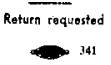

NON-PROFIT ORG. U. S. POSTAGE Paid New York, N. Y. Permit No. 809
Readers are reminded that worldview welcomes correspondence, Letters moy be specific comments on articles in recent issues or genteral discussion, but readers are requested to limit their letters to 500 words. 